\title{
Assessment of indigenous tree species conservation in subsistence agricultural production systems: A case study of Lari Sub-county, Kiambu County, Kenya
}

\author{
KAMAU MARYGORETTI WAWIRA, THUITA THENYA \\ Department of Geography \& Environmental Studies, University of Nairobi, Kenya. Hyslop Building, P.O. Box 72335-00200, Nairobi, Kenya. \\ Tel: +254-0721-471082, `email: tthenya@yahoo.co.uk
}

Manuscript received: 19 July 2017. Revision accepted: 8 October 2017.

\begin{abstract}
Wawira KM, Thenya T. 2017. Assessment of indigenous tree species conservation in subsistence agricultural production systems: A case study of Lari Sub-county, Kiambu County, Kenya. Asian J For 1: 55-63. Conservation of indigenous trees is important because they regulate nutrients, build organic matter of topsoil, fix nitrogen and create habitat for beneficial soil micro-organisms. Subsistence agriculture is a typical land-use system in Kenya, especially in the humid and sub-humid regions. This research aimed to assess the types of indigenous trees, where they are grown, and why they are retained in agricultural production systems in Lari Subcounty, Kiambu County, Kenya. The results showed that various indigenous tree species were retained on-farm including Acacia abyssinica, Olea europaea, Ficus thonningii, Brachylaena hutchinsii, Allophylus abyssinicus, Vitex keniensis, and Prunus africana. The remnants of indigenous trees were scattered on farm with 57.4\% along the boundary, $38.9 \%$ around the homestead, $2.6 \%$ inside the farm and $1.1 \%$ on riverine areas. Soil conservation, and timber and fuelwood provision were given as the main reasons for conserving indigenous tree species on the farm. While the main reason for planting exotic trees on-farm include economic purposes like income, fuelwood, and decreased land sizes, according to $60 \%$ of respondents. Overall, the findings indicate significant decrease in indigenous trees conservation on-farm due to longer maturity span compared to exotic trees. There is a need to promote alternative uses of indigenous trees as well as reinforce the $10 \%$ tree cover to include that $2 \%$ of the latter should be indigenous in nature.
\end{abstract}

Keywords: Conservation, indigenous tree species, on-farm, subsistence agriculture

\section{INTRODUCTION}

Trees have been part of local land-use systems for millennia. The products derived from them, such as food, medicine, cooking fuel, animal fodder and construction materials, are critical for the subsistence living of hundreds of millions of people throughout the world. Trees also have protective functions at site, landscape and global levels. They prevent soil erosion, store water underground, maintain soil fertility, allow more efficient water and nutrient resource use, and contribute to micro-climate moderation. The ecosystem services they provide at a global level in terms of carbon sequestration and biodiversity conservation are also significant.

Around 13 million hectares of forest in the world were converted to other uses, largely agriculture, or lost through natural causes each year in the last decade. This compares with a revised figure of 16 million hectares per year in the 1990s (UNEP 2012). Estimates of the change in forest area over time provide an indication of the demand for land for forestry against other uses.

Removal of trees from agricultural landscapes has for long been seen as a sign of intensification and progress, especially where mechanization of agriculture was involved (Zomer et al. 2014). The agriculture and environment interface, according to Altieri and Nicholls (2005), is a growing source of concern, due to not only the frequently denounced negative effects of agriculture on the environment, but also to the increasingly strong constraints that environmental conservation places on small-scale farmers and collective rangeland management. It is widely recognized that change in agricultural land use is an important driver of biodiversity loss in developing countries (Wretenberg and Berg 2010).

Nonetheless, there is an increasing concern about setting aside tree cover in agricultural landscape. Globally, between years 2000 (averaged 2000-2002) to 2010 (averaged 2008-2010) a statistical analysis by the World Agroforestry Center showed that the amount of tree cover on agricultural land increased substantially, with the area of $>10 \%$ tree cover increases by $3 \%$, or more than 828,000 $\mathrm{km}^{2}$. It is essential that this is recognized by all involved in agricultural production, planning, and policy development (Zomer et al. 2014). The largest increase was in South America with areas having $>10 \%$ tree cover being more than $489,000 \mathrm{~km}^{2}$ : an increase of $12.6 \%$. South Asia also showed a large increase (6.7\%), along with East Asia (5\%), Oceania (3.2\%), and Southeast Asia (2.7\%). In Central America, the area with $>10 \%$ tree cover increased by $1.6 \%$ to reach $96 \%$ of all agricultural land. For Sub-Saharan Africa, the increase was at $2 \%$, while both Northern and Central Asia showed a decrease of $2.9 \%$.

A study by Zomer et al. (2014) showed the importance of trees outside forests on a global scale: almost half of the agricultural land in the world (more than 1 billion hectares) has tree cover of more than $10 \%$. However, in most 
countries, trees outside forests are still poorly reported in the official statistics used to support national decisionmaking and policy. Trees outside forests are thus most often ignored in land-use planning and development policies. One major reason for this lack of information is the difficulty and cost of assessing trees outside forests on a national scale.

Kenya is among developing countries in sub-Saharan Africa that share problems of deforestation with other eastern Africa nations due to conversion of forests to other land uses, especially agriculture and settlement, to meet the needs of ever-increasing human population. In Kenya, limited studies have been carried out to assess factors associated with indigenous tree planting and retention of trees by farmers in order to realize the expected output of improving tree cover (Oeba et al. 2012). The decision by farmers to plant trees may be difficult due to many land-use needs especially agriculture in enhancing food security of about 40 million Kenyans.

Farmlands in Lari Sub-county, Kenya are dotted with remnants of indigenous trees, providing an excellent context for a study of tree cover within agricultural landscapes. Therefore, this research was undertaken to find out the types of indigenous trees, where they are grown and why they are retained in agricultural production systems in Lari Sub-county.

\section{MATERIALS AND METHODS}

\section{Study area}

Geographical location

Lari Sub-county covers an area of $439.20 \mathrm{~km}^{2}$ with elevation ranging between 2415 and $2591 \mathrm{~m}$ above sea level (a.s.1) and receives precipitation between 1,150 and $1,276 \mathrm{~mm}$. The study area covered two wards, first is Kinale Ward, which has an area of $112.3 \mathrm{~km}^{2}$ with a population density of 130 persons per $\mathrm{km}^{2}$ (Figure 1). In this area, the agro-ecological zone supports sheep and dairy farming, tea farming and forestry. The other is Kijabe Ward which has an area of $29.8 \mathrm{~km}^{2}$ with a population density of 711 persons per $\mathrm{km}^{2}$ while the associated agroecological zone supports wheat-maize-barley-pyrethrum farming tea and dairy zone.

Majority of the people in the study area depend on agriculture for their livelihood, with 304,449 directly or indirectly employed in the sector. Coffee and tea are the main cash crops while maize, beans, and Irish potatoes are the main food crops commonly grown on small scale. The majority of the people depend on small-scale farming with the average size of the land being 0.8 ha. The land is purely an agriculture zone and agricultural practices are raindependent. In relation to the land quality, Lari lies in the high to moderate fertility where livestock, tea, coffee, and horticulture agro-enterprises are practiced. The soils are well-drained, extremely deep, grey or red or dark brown friable clays.

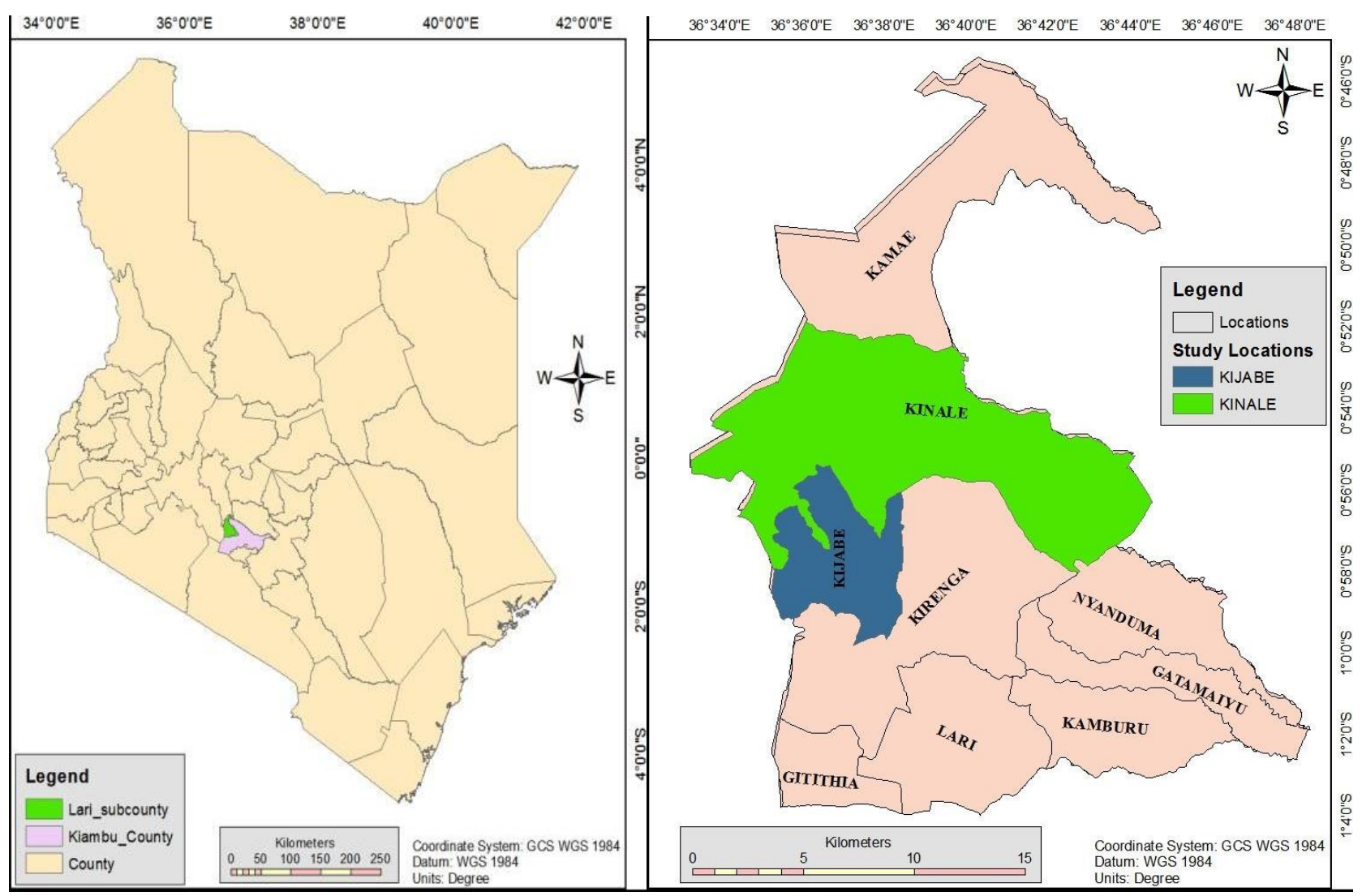

Figure 1. Map showing the study areas in Kinale and Kijabe, Lari Sub-county, Kenya 


\section{Study design}

The study design adopted for this research was both descriptive as well as cross-sectional research designs. The study was designed to capture two agro-ecological zones; these were selected through purposive sampling based on the agro-ecological characteristics and population size. The sample selected through multi-stage sampling was subjected to both observation and interrogative data collection. However, only a cross-section of farmers was selected to participate in the study since data collection was only done for farms along major roads. The purpose of selecting these farms was based on the assumption that farms nearer to the major road networks hardly had any indigenous trees because of the already high demand for timber.

The first sampling point was at the Sub-county administrator office of each sub-location and then $5^{\text {th }}$ farm to the right side of the road after the Sub-county administrator office and thereafter every $5^{\text {th }}$ household alternating across the road. A total of 96 farms were sampled based on population with Kinale having $60 \%$ of the sample population (57 households) and Kijabe $40 \%$ of the population (39 households). Agricultural field officers were engaged during data collection to assist in identification of the various indigenous trees on-farm while structured questionnaires were used to collect views from the 96 farmers. A walk in farm understudy after getting permission from the owner was necessary for effective data collection. The position of the trees on farm was marked by Global Positioning Systems to be combined with tree inventory observation schedule. Data collected included relative position, height, breadth and reasons for maintaining the trees on the farm. Photographic evidence of the trees on the farm was also taken. The research encouraged the farm owner to take the walk together on farm to help identify the name of tree in local language.

\section{Data analysis}

Data from the questionnaire were entered into SPSS analyzed through descriptive statistics while correlational analysis was to show how variables were related. Indices for various measures were also computed. The Likert scale $(0-5)$ was also used to show degree of influence. On spatial analysis, the GPS points that were recorded in degrees and minutes were first converted to decimal degrees for compatibility with the GIS software (ArcGIS). The converted data layers (for Kijabe and Kinale) were displayed in the GIS software (ArcGIS) and converted to GIS layers. The layers were then overlaid on Kijabe and Kinale Wards layers for map preparation.

\section{RESULTS AND DISCUSSIONS}

\section{Tree species richness}

Several species of indigenous tree species were found on farm in both Kinale and Kijabe Wards, Lari Sub-county, Kenya (Table 1). These included trees such as MukeuKikuyu or dombeya (Dombeya torrida), croton tree (Croton megalocarpus), melia (Melia volkensii), etc.
Table 1. Indigenous trees on farm in Lari Sub-county, Kenya

\begin{tabular}{lll}
\hline Local name & Common name & Scientific name \\
\hline Murera & Thorn tree & Acacia abyssinica \\
Mokumo/mugumo & Strangler fig & Ficus thonningii \\
Mubuu & Silk oak & Brachylaena hutchinsii \\
Muchami & Allophylus & Allophylus abyssinicus \\
Muhoro/muhoru & Meru oak & Vitex keniensis \\
Muiri & Red stinkwood & Prunus africana \\
Mukau & Melia & Melia volkensii \\
Mukeu & Dombeya & Dombeya torrida \\
Mukindori & Croton & Croton megalocarpus \\
Mutamaiyu & African olive & Olea europeana \\
Mutarakwa & African juniper & Juniperus procera \\
Mutati & Parasol tree & Polyscias kikuyuensis \\
Muthai & Schefflera & Schefflera volkensii \\
Muthegera & Podo & Podocarpus milanjianus \\
Mugaita & Rapanea & Rapanea ralanophloes / \\
& & Myrisna melanophloes \\
\hline
\end{tabular}

\section{Tree diversity}

Table 2 and 3 show a diversity index of the indigenous tree species found on farm in Lari Sub-county per ward. A diversity index is a quantitative measure that reflects how many different types (such as species) there are in a dataset, and simultaneously takes into account how evenly the basic entities (such as individuals) are distributed among those types. The value of a diversity index increases both when the number of types increases and when evenness increases. From Table 2 and 3, it is clear there was a high highest diversity of indigenous tree species in Kijabe than Kinale Ward. Meru Oak (Vitex keniensis) dominated in Kijabe while the African juniper (Juniperus procera ) tree dominated the Kinale Wards farms.

The lowest diversity was the silk oak (Brachylaena hutchinsii) and rapanea (Rapanea melanophloeos) in both Kinale and Kijabe Wards. There was no strangler fig, silk oak and rapanea tree species in Kijabe and in Kinale there was no allophylus (Allophylus abyssinicus), croton (Croton megalocarpus), schefflera (Schefflera volkensii) and thorn trees (Acacia abyssinica) recorded on farm. While the parasol and podo trees occurred in both Kijabe and Kinale Ward.

\section{The location of indigenous trees species on farm}

The study analyzed where these indigenous trees grew most within Lari Sub-county. This was categorized into 4 regions. Scattered on farm (SF): these are trees that grew almost anywhere inside the farm but not near the homestead area. Boundary trees (B): these trees are those that were grown purposively as fences to mark the boundary between one farm and the other. Homestead $(\mathrm{H})$ : this showed the trees that grew near the homestead area but not where the farmer was practicing agriculture. Riverine $(\mathrm{R})$ : these are the trees that grew along streams/rivers that were passing via the farms.

Overall, most of the trees in Lari Sub-county were scattered on farm $(57.4 \%)$ (Table 4$)$. This could be because trees create a conducive ecosystem that encourages agricultural undergrowth thus the rationale to leave them 
there or plant. Only $1.1 \%$ of the trees were found on riverine areas.

The highest numbers of indigenous trees in Kinale Ward were mostly located at the boundary and some of these trees included African juniper (J. procera), dombeya (D. torrida) and podo (P. milanjianus) (Table 5; Figure 2).
All the indigenous trees found in Kinale were also found at the homesteads. Dombeya (D. torrida) had the highest number of trees scattered on various farms in Kinale Ward. The Red stinkwood (Prunus africana) tree is found majorly on riverine areas while the podo ( $P$. milanjianus) tree has the highest diversity within the homestead.

Table 2. Indigenous tree occurrence in Kinale Ward, Lari Sub-county, Kenya

\begin{tabular}{cccccccccccc}
\hline $\begin{array}{c}\text { Name of } \\
\text { tree }\end{array}$ & $\begin{array}{c}\text { African } \\
\text { juniper }\end{array}$ & $\begin{array}{c}\text { African } \\
\text { olive }\end{array}$ & Dombeya & $\begin{array}{c}\text { Meru } \\
\text { oak }\end{array}$ & $\begin{array}{c}\text { Parasol } \\
\text { tree }\end{array}$ & Podo & Rapanea & $\begin{array}{c}\text { Red } \\
\text { stinkwood }\end{array}$ & $\begin{array}{c}\text { Silk } \\
\text { oak }\end{array}$ & $\begin{array}{c}\text { Strangler } \\
\text { fig }\end{array}$ & $\begin{array}{c}\text { Total } \\
\text { Rrequency }\end{array}$ \\
6612 & 89 & 70 & 32 & 9 & 94 & 1 & 89 & 15 & 2 & 7013 \\
\hline percentage & 94.28 & 1.3 & $1: 00$ & 0.46 & 0.13 & 1.54 & 0.01 & 1.3 & 0.01 & 0.03 & 100 \\
\hline
\end{tabular}

Table 3. Indigenous tree occurrence in Kijabe Ward, Lari Sub-county, Kenya

\begin{tabular}{|c|c|c|c|c|c|c|c|c|c|c|c|c|}
\hline $\begin{array}{c}\text { Name of } \\
\text { tree }\end{array}$ & $\begin{array}{l}\text { African } \\
\text { Juniper }\end{array}$ & $\begin{array}{c}\text { African } \\
\text { Olive }\end{array}$ & Dombeya & $\begin{array}{c}\text { Meru } \\
\text { Oak }\end{array}$ & $\begin{array}{c}\text { Parasol } \\
\text { tree }\end{array}$ & Podo & $\begin{array}{c}\text { Red } \\
\text { stinkwood }\end{array}$ & Allor & $\begin{array}{l}\text { Silk } \\
\text { Oak }\end{array}$ & lera & $\begin{array}{c}\text { Thorn } \\
\text { tree }\end{array}$ & Cotal \\
\hline requency & 94 & 23 & 2 & 10003 & 14 & 14 & 126 & 2 & 5 & 3 & 10 & 10641 \\
\hline percentage & 0.91 & 0.29 & 2.84 & 94.22 & 0.14 & 0.14 & 1.22 & 0.03 & 0.06 & 0.05 & 0.10 & 100 \\
\hline
\end{tabular}

Table 4. Relative position of indigenous trees on farm in the two locations (Kinale and Kijabe Wards) in Lari Sub-county, Kenya

\begin{tabular}{llllll}
\hline Relative position of tree on farm & Scattered on farm & Boundary & Homestead & Riverine & Total \\
\hline Frequency & 10134 & 6876 & 456 & 188 & 17654 \\
Percentage & 57.4 & 38.9 & 2.6 & 1.1 & 100 \\
\hline
\end{tabular}

Table 5. Relative position of indigenous trees in Kinale Ward, Lari Sub-county, Kenya

\begin{tabular}{|c|c|c|c|c|c|c|c|c|c|c|c|}
\hline \multirow[b]{2}{*}{ Relative location of tree } & \multirow[b]{2}{*}{$\begin{array}{l}\text { African } \\
\text { juniper }\end{array}$} & \multirow[b]{2}{*}{$\begin{array}{c}\text { African } \\
\text { olive }\end{array}$} & \multirow[b]{2}{*}{ Dombeya } & \multicolumn{4}{|c|}{ Name of indigenous trees } & \multirow[b]{2}{*}{$\begin{array}{c}\text { Red } \\
\text { stinkwood }\end{array}$} & \multirow[b]{2}{*}{ Silk oak } & \multirow[b]{2}{*}{$\begin{array}{l}\text { Strangler } \\
\text { fig }\end{array}$} & \multirow[b]{2}{*}{ Total } \\
\hline & & & & $\begin{array}{l}\text { Meru } \\
\text { oak }\end{array}$ & $\begin{array}{c}\text { Parasol } \\
\text { tree }\end{array}$ & Podo & Rapanea & & & & \\
\hline Boundary & 6608 & 2 & 22 & 6 & & & & 3 & & & 6641 \\
\hline Scattered on farm & & 5 & 36 & 5 & 6 & 5 & & 1 & 15 & & 73 \\
\hline Riverine & & 60 & 5 & 5 & 3 & & 1 & 70 & & & 143 \\
\hline Homestead & 4 & 22 & 7 & 16 & & 89 & & 15 & & 2 & 156 \\
\hline Total & 6612 & 89 & 70 & 32 & 9 & 94 & 1 & 89 & 15 & 2 & 7013 \\
\hline
\end{tabular}

Table 6. Relative position of indigenous trees in Kijabe Ward, Lari Sub-county, Kenya

\begin{tabular}{|c|c|c|c|c|c|c|c|c|c|c|c|c|}
\hline \multirow[b]{2}{*}{$\begin{array}{c}\text { Relative location of } \\
\text { tree }\end{array}$} & \multicolumn{10}{|c|}{ Name of indigenous trees } & \multirow[b]{2}{*}{$\begin{array}{c}\text { Thorn } \\
\text { tree }\end{array}$} & \multirow[b]{2}{*}{ Total } \\
\hline & $\begin{array}{l}\text { African } \\
\text { juniper }\end{array}$ & $\begin{array}{c}\text { African } \\
\text { olive }\end{array}$ & Dombeya & $\begin{array}{c}\text { Meru } \\
\text { oak }\end{array}$ & $\begin{array}{c}\text { Parasol } \\
\text { tree }\end{array}$ & Podo & $\begin{array}{c}\text { Red } \\
\text { stinkwood }\end{array}$ & Allophylus & Croton & Schefflera & & \\
\hline Boundary & 26 & 16 & 143 & & 5 & 12 & 23 & & & & 10 & 235 \\
\hline d on farm & & & 60 & 10000 & & & 1 & & & & & 10061 \\
\hline Riverine & & 3 & 40 & 1 & 1 & & & & & & & 45 \\
\hline Homestead & 68 & 4 & 54 & 2 & 8 & 2 & 102 & 2 & 55 & 3 & & 300 \\
\hline Total & 94 & 23 & 297 & 10003 & 14 & 14 & 126 & 2 & 55 & 3 & 10 & 10641 \\
\hline
\end{tabular}




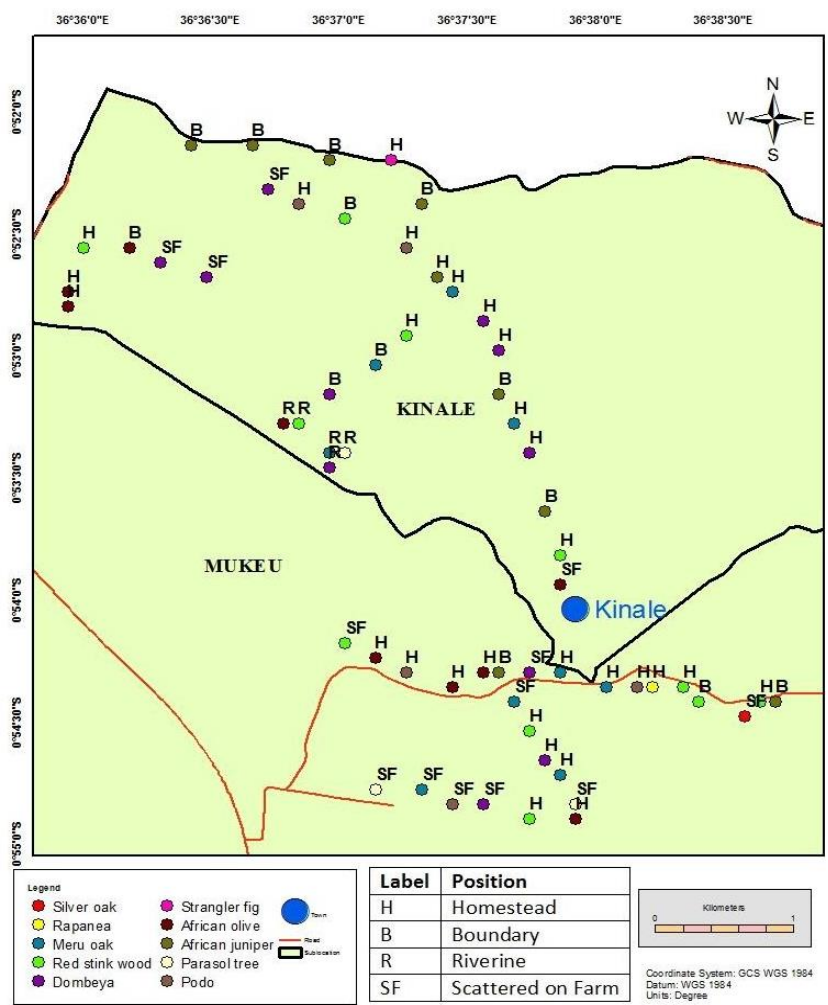

Figure 2. Indigenous tree sites in Kinale Ward, Lari Sub-county, Kenya

Figure 3 and Table 6 show the relative position of indigenous trees in Kijabe Ward and it shows that Meru oak (V. keniensis) had the highest diversity in Kijabe and most of it is scattered within the farms. The Red stink wood ( $P$. africana) had the highest diversity in terms of trees found within the homestead while dombeya $(D$. torrida) had the highest diversity in terms of trees found within boundary and riverine areas. Most of the trees were concentrated in Mbauini, Bathi and Kijabe subdivisions and very little indigenous trees were found in Magina.

From the 39 farms visited in Kijabe, the study counted 10,641 indigenous trees. On the other hand, 7,013 indigenous trees were found in the 57 farms visited in Kinale. Some of the indigenous tree compositions found in Lari include A. abyssinica, Ficus thonningii, B. hutchinsii, A. abyssinicus, V. keniensis, Prunus africana. These trees relative location was majorly homestead, boundary and scattered on farm. There is a high population of indigenous trees found in Mukeu as opposed to Kinale Wards. The reason for fewer indigenous tree species on farm in Kinale was primarily because most of the farms practiced horticultural farming. This system of production mainly requires specialization of either crop mainly cabbages, potatoes, carrots, beetroot, cucumber to name a few and fruit trees.

\section{Rationale for retaining indigenous trees on farm}

There are various reasons as to why indigenous trees are retained on farm in Lari Sub-county. Growing trees can be an induced innovation to help maintain agricultural productivity because they may reduce soil erosion and

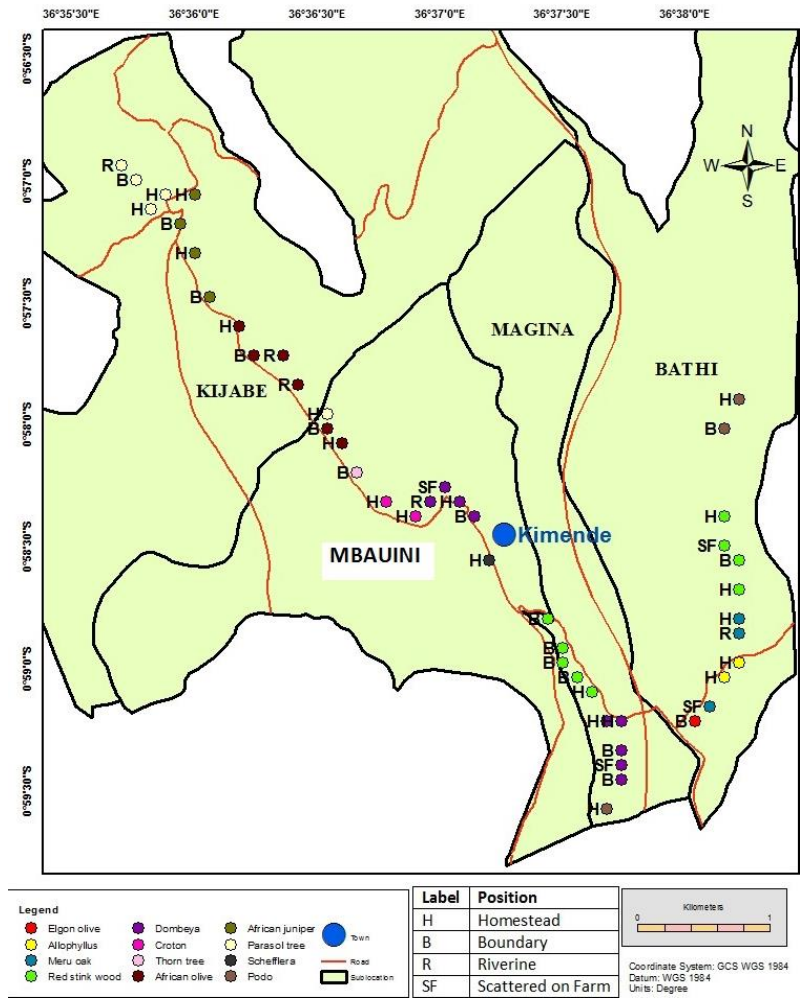

Figure 3. Indigenous tree sites in Kijabe Ward, Lari Sub-county, Kenya

enrich the soil (Scherr 1995) or increase carrying capacity of the shallow soils (Carson 1989). It is a livelihoods' option often mentioned and increasingly promoted by landuse managers and international development agencies (Zomer et al. 2014). Farmer's willingness to grow trees depends on many factors (Filius 1997). The research study sought to find out the factors that actually influenced farmers to retain indigenous trees on their farms.

\section{Degree of influence of factors affecting conservation of indigenous trees on farm in Lari Sub-county}

We used a Likert scale (0-5) to describe the degree of influence 0 meant to a very low extent while 4 meant to a great extent. Among the factors analyzed on what influences farmers to retain or conserve the indigenous trees on farm included agricultural and environmental conservation practices, indigenous knowledge on value of tree, benefits derived from having the indigenous species in mixed farming, practicing intensive farming, or monoculture and agricultural officer recommendation.

Major factor influencing the conservation of indigenous trees on farm in Kinale Ward in Lari Sub-county is due to the benefits derived from having indigenous tree species in mixed farming and the knowledge on the value of indigenous trees (Figure 4). The total number of indigenous trees found in Kinale was 7,012 from the farms visited, which was lower than in Kijabe, which could be due to the fact most of the farmers practice horticultural farming including potatoes, French beans, cabbages and kales among others. 
In Kijabe, a total of 10,641 indigenous tree species were counted in the 39 farms visited. Similarly, mixed farming and knowledge of indigenous trees were noted as important factors influencing conservation of indigenous trees (Figure 5). In both wards, the influence of knowledge on environmental conservation coupled with influence from agriculture contributed to the retention of indigenous trees on the farm.

\section{Gender influence on indigenous tree conservation}

There were various factors that influence the indigenous tree species on the farm. Household characteristics were one of the factors that influence the presence or absence of indigenous tree species on farm and most often than not dictate where these trees are located on the farm. In the study, men have close to $80 \%$ control on deciding which species to have on the farms in Lari Sub-county. Gender, and cultural beliefs and taboos play an important role in conservation of tree species on the farm. The socially ascribed gender roles in relation to tree planting activities and use of tree resources can have significant implications for tree planting. For instance, although women provide labor in planting and managing trees, it is the men who decide on use and disposal of tree resources (Ndei 2014). The presence of cultural beliefs and taboos associated with planting can have an impact on conservation of useful tree species on the farm as they inhibit conservation of certain tree species. Traditionally, planting or cutting of certain tree species was prohibited and this helped to conserve some of the endangered indigenous species. Although these cultural beliefs affect men and women, they were more restrictive to women when it comes to participation in conservation of trees. Women in most cases cannot take decisions on issues concerning tree cutting and selling in the community; male permission was usually sought.
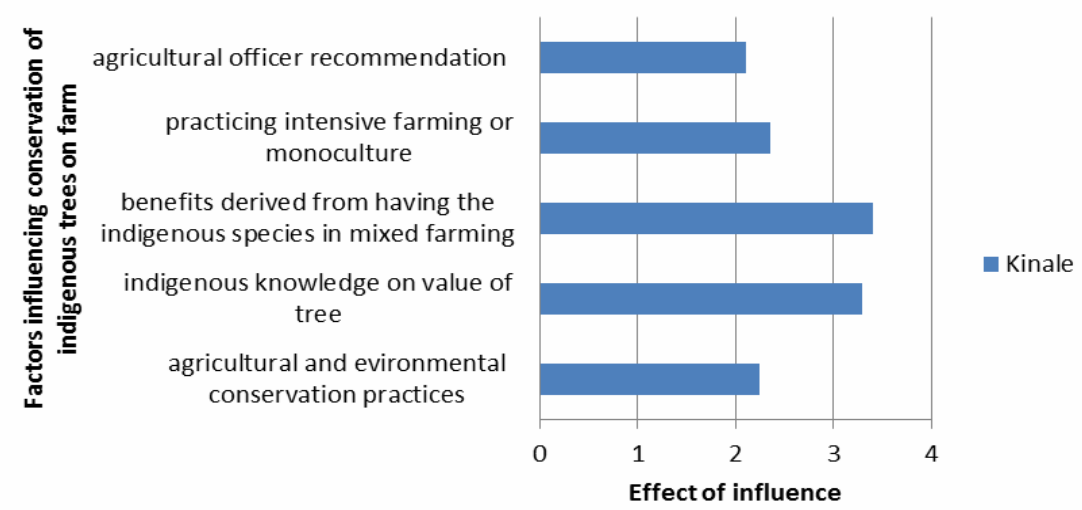

Figure 4. Degree of influence of factors affecting conservation of indigenous trees on farm in Kinale Ward, Lari Sub-county, Kenya
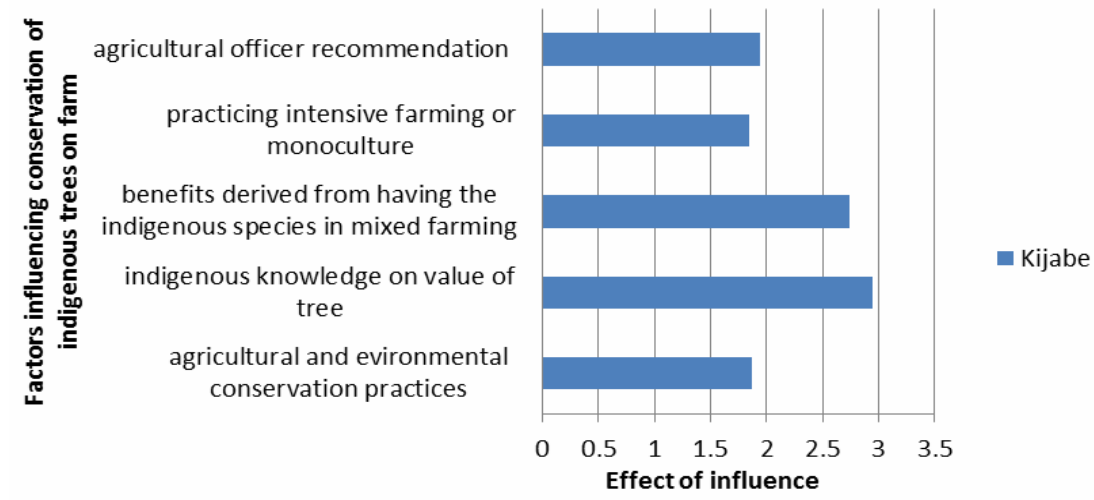

Figure 5. Degree of influence of factors affecting conservation of indigenous trees on farm in Kijabe Ward, Lari Sub-county, Kenya

Table 7. Level of education of respondents conserving indigenous trees in Lari Sub-county, Kenya

\begin{tabular}{|c|c|c|c|c|c|c|c|}
\hline & \multicolumn{7}{|c|}{ Educational level of household } \\
\hline Highest level of education & University & College & Secondary & Upper primary & Lower & Did not go to school & Total \\
\hline Indigenous trees frequency on farm & 5 & 4 & 29 & 35 & 18 & 5 & 96 \\
\hline Percentage & 5.2 & 4.2 & 30.2 & 36.5 & 18.8 & 5.2 & 100 \\
\hline
\end{tabular}




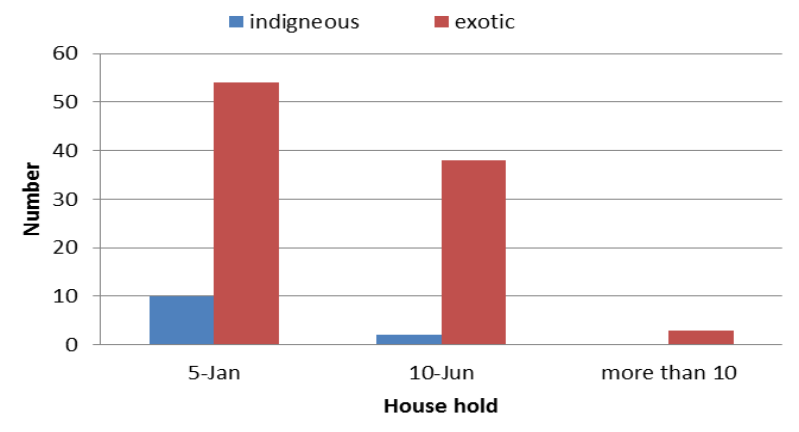

Figure 6. Household size and agricultural intensification

\section{Influence of education levels on indigenous tree species diversity}

Behavior change in different communities is primarily influenced by the level of education of the constituents. In Lari Sub-county, major household heads had a moderate education level of $30.2 \%$ and $36.5 \%$ at both secondary and upper primary respectively. It is notable that people with university education move out of village in search of jobs. From Table 7, those household heads with no or low education levels conserved small number of indigenous tree species on farm compared to those with relatively higher level of literacy. This indicates that ingenious education is a part of respondents' cultural and social identities, well-being, sustainable development and intellectual and cultural vitality which plays a crucial role in the successful conservation of the environment.

\section{Agricultural intensification and its influence in indigenous trees conservation}

The household size in both Kinale and Kijabe ranged from 1 to 10 persons per household. This number depicted the actual number of members living in the households during the study period. Figure 6 shows that the bigger the household size the less the indigenous trees that existed on farm. Only $10 \%$ of the indigenous trees existed in households having 1-5 persons and approximately $2 \%$ for those having 6-10 persons whereas there were no indigenous trees in households that had more than 10 persons per household. The study assumes that the higher the population pressure on farmland may directly affect the economic activity on farm. Therefore most of the farms that had many people, the food requirement needs are higher and thereby high agricultural intensification as opposed to tree planting. The study, therefore, echoes Boserup's theory on population growth and agricultural intensification. Agriculture is the predominant economic activity within Kiambu county. It is the leading sub-sector in terms of employment, food security, income earnings and overall contribution to the socio-economic wellbeing of the people. The agricultural production system mostly practiced in both Kinale and Kijabe is mixed cropping. Agricultural production systems are mostly influenced by household sizes. The higher the household size the less the conservation of indigenous trees.

\section{Uses of indigenous trees vs exotic}

There were various uses of indigenous trees documented in Lari constituency. This is one of the rationale why some of the farmers still have indigenous tree species on farm. Some trees have medicinal properties like Ficus thoorgingii, A. abyssinica, A. abyssinicus, $P$. africana, C. megalocarpus and Octea usambarensis. These trees can be used to treat diarrhea, hemorrhage, jaundice, headaches, burns, venereal diseases, etc. Other trees are specially used as insect repellants or as acaricides such as A. abyssinica. Podocarpus milanjanus, V. keniensis, A. abyssinica, and $P$. africana make very good timber for construction. Indigenous trees also make very good fodder for animal and can therefore be used as feed e.g. the $A$. abyssinica and $M$. volkensii. Others have cultural values such as Ficus thonningii (Mugumo) that were used sacred sites traditionally and up to now community avoids cutting it waiting for it to fall on its own.

The low levels of likelihood of farmers to plant and retain trees in Lari Sub-county may be attributed to small landholdings due to high population especially in Kijabe where the land sizes are significantly smaller. In Kinale, the nature of their farming activities was dairy, horticultural and subsistence crops. This may have delineated them from active participation in tree farming as most of the land was needed for pasture and food crops. This was in contrast with Kijabe where the farm sizes were smaller and the major motivation of planting indigenous trees on farm was due to the sensitization efforts by KENVO (Kijabe Environmental Volunteers) and also the presence of the Ministry of Agriculture within the ward that encourage tree planting. Discussions held with farmers during data collection in this region pointed out that majority of them viewed indigenous tree growing as a long-term investment with no immediate cash to offset household needs, hence lowly prioritized. Therefore, chances of finding indigenous trees on farm of varied sizes were small reflecting less retention. There is high market for poles in Lari Sub-county, therefore, farmers resort to planting more and more exotic trees.

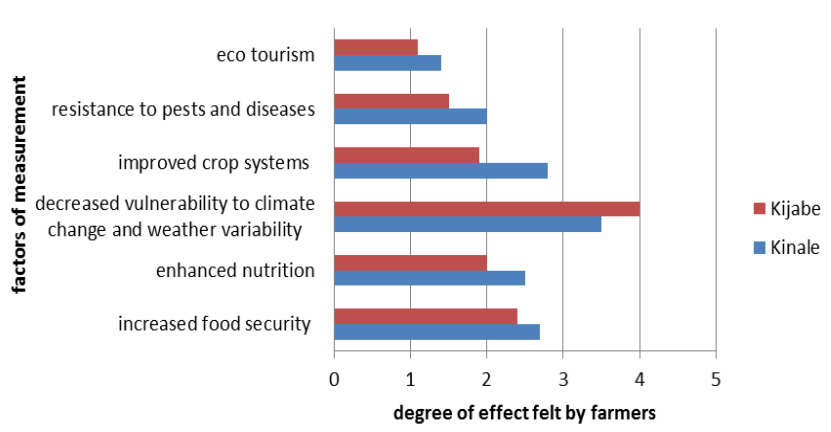

Figure 7. Benefits of indigenous trees on farm in Kinale and Kijabe Wards, Lari Sub-county, Kenya 


\section{Effect of indigenous trees on farm}

Trees in farming systems are found either in forest fallows within shifting cultivation systems; as relics from land clearance by slash-and-burn, or as a result of deliberate management and/or planting. The integration of indigenous trees in farming systems to provide environmental services and/or products that are either traded or used domestically to confer multiple livelihood benefits, especially for smallholder farmers in the tropics beset poverty, malnutrition, and hunger. The most important factor was decreased vulnerability to climate change and weather variability along with enhanced food security (Figure 7). It is important to note that the numbers of trees in farmland can contribute to the restoration of lost productive capacity in farmland, especially infertile degraded land, through the rehabilitation of agroecosystem functions. Other values of the trees on farm include the creation of new opportunities for greater and more diversified production with enhanced utility and profitability through the domestication of indigenous tree species conferring nutritional and health benefits. In addition to promotion of local enterprise, value-addition, entrepreneurism and job creation in rural communities through commercialization.

In conclusion, there were indigenous tree species found in Lari Sub-county. There were more indigenous trees in Kijabe than Kinale Wards. Most of the indigenous tree species in Lari Sub-county were found scattered on the farm and this can be attributed to their importance of regulating nutrients, building organic matter of topsoil, fixing nitrogen and creating habitat for beneficial microorganisms. There are very few indigenous tree species growing in riverine areas and homesteads. Their presence was influenced by gender, education levels, socioeconomic activity, and agricultural production system practiced based on household sizes.

Indigenous trees were still retained in Lari Sub-county and the reasons for this are attributed to their effect on the environment as a buffer for food security and decreased vulnerability to climate change. They were also retained due to major efforts that have been put in place by the Ministry of Agriculture through agricultural extension officers. Residents in Lari recognized that there are very many benefits from indigenous trees, ranging from medicinal to timber, and it is important to preserve these trees for future generations. This study, therefore, recommends sensitization campaigns among the farming community to promote indigenous tree conservation so as to contribute towards the country's target of $10 \%$ tree cover.

\section{REFERENCES}

Altieri M, Nicholls C. 2005. A Rapid, Farmer-Friendly Agro-Ecological Method to Estimate Soil Quality and Crop Health in Vineyard Systems. Agroecology and the Search for a Truly Sustainable Agriculture. PNUMA, 277, 290.

Filius AM. 1997. Factors changing farmers' willingness to grow trees in Gunung Kidul (Java, Indonesia). Netherlands J Agric Sci 45: 329345. DOI: $10.18174 /$ njas.v45i2.521

Ndei C. 2014. Gendered Perspective of Cultural Factors that Influence Conservation of Useful Tree Species in Igembe South Sub-county, Upper Eastern Region. [Thesis]. University of Nairobi, Kenya.

Oeba VO, Otor SCJ, Kungu JB, Muchiri MN. 2012. Modelling determinants of tree planting and retention on farm for improvement of forest cover in Central Kenya. ISRN Forestry 2012: 867249. DOI: $10.5402 / 2012 / 867249$.

Scherr. SJ. 1995. Meeting household needs: farmer tree-growing strategies in western Kenya. In: Arnold JEM, Dewees PA (eds.). Tree Management in Farmer Strategies: Responses to agricultural intensification. Oxford University Press, Oxford.

UNEP. 2012. The Role and Contribution of Montane Forests and Related Ecosystem Services to the Kenyan Economy. United Nations Environmental Programme, Nairobi, Kenya.

Wretenberg JTP, Berg A. 2010. Changes in local species richness of farmland birds in relation to land-use changes and landscape structure. Biol Conserv 143: 375-381.

Zomer R J, Trabucco A, Coe R, Place F, Van-Noordwijk M, Xu JC. 2014. Trees on farms: an update and reanalysis of agroforestry's global extent and socio-ecological characteristics. Working Paper 179. World Agroforestry Centre (ICRAF) Southeast Asia Regional Program, Bogor, Indonesia. 